International Journal of English Literature and Social Sciences
Vol-6, Issue-5; Sep-Oct, 2021
Journal Home Page Available: https://ijels.com/
Journal DOI: $10.22161 /$ ijels

Peer-Reviewed Journal

\title{
The Pedagogical Practice and the Use of Technology during the Construction of Knowledge in the Present Days
}

\author{
Francisco de Assis de Carvalho Almada ${ }^{1}$, Francisca Morais da Silveira ${ }^{2}$, Herli de Sousa \\ Carvalho $^{3}$, Ilma Maria de Oliveira Silva ${ }^{4}$, Maria Zilma Rodrigues Silva ${ }^{5}$, Paula \\ Alexandra Trindade Mota ${ }^{6}$
}

\footnotetext{
1,2,3,4Professor of the Postgraduate Program in Teacher Training in Educational Practices, Federal University of Maranhão (UFMA), Brazil 5,6 Master's Degree student of the Postgraduate Program in Teacher Training in Educational Practices, Federal University of Maranhão (UFMA), Brazil
}

Received: 16 Aug 2021; Received in revised form: 17 Sep 2021; Accepted: 24 Sep 2021; Available online: 03 Oct 2021 (C)2021 The Author(s). Published by Infogain Publication. This is an open access article under the CC BY license (https://creativecommons.org/licenses/by/4.0/).

\begin{abstract}
Our This article aims to approach the pedagogical practice combined with the use of technology in the construction of teaching knowledge of present times. To that effect, we will conduct a reflection on the teaching work, that is: how education professionals are reinventing themselves to meet the demands during the pandemic of covid-19, and particularly how teachers are developing their educational practices in this new format of remote classes through digital platforms. This because, with the pandemic, face-to-face classes were suspended for all school systems, be them public or private, municipal, state or federal. Social isolation was one of the safety measures adopted as a way to avoid contamination. In this sense, it is necessary that the teacher seeks new skills to meet the demand in their daily practices with their students, identifying the advantages and possible difficulties during the development of teaching learning, from the use of these new technological tools, such as: mobile phones, laptops, the internet, among others. With this, they demonstrate how the novel technologies have required for teachers to seek training, to adapt themselves to the development of the current skills and abilities that this moment demands, and thus advance in the construction of knowledge as a mediator of pedagogical practice in the era of information technology in a delicate moment of pandemic.
\end{abstract}

Keywords - Remote Classes, Pedagogical Practice, Pandemic, Teaching Knowledge, Technologies.

\section{INTRODUCTION}

We bring forth a reflective analysis on the educational pedagogical practice during the covid-19 pandemic, discussing the relevance of the use of novel technologies as a way to decrease the impact of the absence of face-toface classes. The covid-19 (coronavirus), since its first recorded cases on December 19th, at Wuhan, China, has spread all around the world, causing a high number of deaths and forcing countries to adopt a few security protocols, such as the use of masks, widespread use of gel alcohol, social distancing, among others. This pandemic has shaken the political, economic and social structures of our planet, as it is a highly infectious and still largely unknown disease.

Thus, to avoid contagion and overcrowding of hospitals, what would impede their due service to the population, classes inside classrooms were suspended in all cities of Brazil. It was in this context that we adopted remote education, what brought several changes to the teaching learning process. Professors had to adapt themselves to experience novel ways of teaching, and students had to discover novel ways and opportunities for learning. Therefore, teaching institutions starting using technology as an ally to pass on teaching knowledge. With this, teachers appropriated these new technological tools and 
started to carry out new approaches, strategies and techniques in the mediation of knowledge. However, this new teaching format is not accessible to everyone, as a large portion of our population does not have access to technology. Keeping an active link with these students has thus become a challenge, in addition to revealing the need for other measures not to increase exclusion.

What is known is that novel information technologies are present in the daily lives of people from all age groups, in several forms: TV, laptops, cell phones, among others, to serve various purposes. Following this line of thought, pedagogical practice and the use of novel information technologies may be used as tools for professors to diversify their methods and teaching techniques during this moment of social isolation and, from there, make their classes more attractive and participative. It is necessary to know and learn how to use technology tools, and many teachers needed to improve themselves to deal with this new education reality.

It is in this sense that we aim to analyze the pedagogical practice and the use of technology during the construction of knowledge in our present time, where teachers and family members had to alter their routines and follow a safety protocol. All with the objective of obtaining positive results for education, where education professionals employ their roles as educators in face of new challenges and, with this, hope to construct an emancipated learning.

Thus, the role of the teacher facing these new technological challenges is essential in the mediation of knowledge, as it is by interacting with their student audience, adding new technologies to their learning, that education improves in quality and, from these practices, constitutes a process of social transformation.

\section{PEDAGOGICAL PRACTICE DURING PANDEMIC TIMES}

Education as a process of development of the physical, intellectual and moral capacity of the human person has always been the target of several discussions and frequent worry throughout history. These discussions and worries motivated the evolution of education in many aspects, particularly those related to the methods and techniques of teaching, conducted by educators in their daily practice inside classrooms.

Right now, the teaching practice has revealed itself to be quite diversified, with the incorporation of novel resources, such as movies, music, documentaries, among others, which demand a good qualification from the professor. With the advent of these novel languages in teaching learning and with the emergence of the pandemic, it is necessary and urgent for schools to update themselves in the face of the great changes that have arisen in the technological and cultural field and also for them to understand that there are many social differences in our country and that it is also necessary to advance in the fight against school dropout.

Several researchers make suggestions and discuss on the importance of the insertion of novel methods, techniques, languages, as well as novel research sources for the pedagogical practice inside classrooms. These modern times demand for professors to be up to date and to innovate their methods of teaching, this way mediating relations between subjects, the world and its representations.

These practices are necessary to provide the student with the experience of participating in the educational process. The school needs to be attentive to the changes and needs of students, through material support to meet the new requirements. Maria Lúcia Serafim states that:

In order to enforce its social responsibility to educate and train new citizens, the school needs to have teachers who are willing to capture, understand and use the new languages of the information and communication media at the service of its pedagogical practice, which must be understood as a specific form of praxis, therefore, social practice that involves theory and practice, characteristic of educational practice (SOUSA; MOITA; CARVALHO, 2011, p. 26).

We perceive, with this, that education is a continuously changing process and that it is increasingly necessary for the education professional to be conscious of their role as an educator who needs to be constantly learning, given the fact that the student has access to novelties and information about events in real time. However, knowledge is not training; this is one of the lessons that the covid-19 pandemic taught us, that is:

With social isolation, resulting from the distancing policy, schools and, consequently, students and teachers found themselves with the need to massively use digital tools to replace face-to-face classes. This event severely exposed inadequacies of the education in our country. We can say that some of these insufficiencies are the lack of specific training for teachers, lack of 
understanding by our society, and the precarious access of the school community to technological resources, such as computers and good internet. (SILVA; PETRY; UGGIONI, 2020, p. 20).

We can grasp from this that our country needs to look for ways to remedy this deficiency, both with regard to specific training for teachers, as well as to the precarious access by the student community. Furthermore, teaching requires awareness of the unfinished, common sense, commitment and availability for dialogue. According to Paulo Freire: "Those who teach learn by teaching, and those who learn teach by learning." (FREIRE, 2005, p. 23).

This means that the act of teaching is a sum of factors that involves theory, practice, creativity, competence and dialogue. Therefore, education as a human action is constantly changing. Thus, teachers need to be aware and qualify to act competently in the face of difficulties and challenges that arise in the teaching and learning process.

Therefore, in our current reality, it is possible to see that education is experiencing a moment of transition and transformation. It is within this new experience that Kirchner says:

Knowing that experiences lived by each one of us are under the marks of countless questions for which we have no answers, all pedagogical experiences taught us to ask questions, because they are the great mobilizers of ideas, and the position of those who make questions places us in the search for answers to reality (KIRCHNER, 2020, p, 47).

If questions are important, they are necessary in this period of pandemic, since it is from them that the movement of ideas happens to find effective answers for a better development of remote education, as well as finds ways to face the pandemic.

This situation calls for a reeducation on the part of teachers for their work with students. Arroyo, reporting his experiences, says:

When I go back to my laptops and reread the notes, I find testimonies that are repeated: "today I see students differently"; "with another look"; "I pay more attention to their reactions and their feelings"; "each student is someone with their own story"; "our attention to students is different"; "from repeating cycles of training, times of life, children, teenagers, I even ended up changing my language, the terms I used: repeat student, newbie, slow, outdated... I now find strange..." Not all reactions are of fear and mistrust in front of students (ARROYO, 2014, p. 55).

During these times of pandemic, we need to have a more cautious, patient and generous eye towards students, taking into consideration their history and difficulties in face of this new form of classes. Maria Lúcia says that: "The classroom is not the only space where learning takes place, and communication could provide, through several methods, the formation of different learning environments and greater student participation in teaching relationships" (SOUSA; MOITA; CARVALHO, 2011, p. 26)

It is clear from this that education needs to be in continuous innovation both in terms of content, and regarding methods and techniques for teaching and learning.

According to Araújo and Yoshida:

The 21st century educator must be an education professional who creatively elaborates theoretical and critical knowledge about reality, even if he has to focus on a successful pedagogical practice, with satisfactory and meaningful learning, given the constant changes that have taken place in society, which require a new attitude from the teacher, as well as a critical rethinking about education. Therefore, it is necessary to seek new paths and new projects, emerging from the needs and interests of those responsible for education. It is necessary to transform the school reality, using new ICTs as resources to improve and motivate the search for knowledge (ARAÚJO; YOSHIDA, 2009, p.3).

In fact, changes have always taken place in society. Creativity, theoretical and critical knowledge of the reality we live in, are necessary for a successful learning. To Franco:

[...] in life, what results from the action of good teaching will always be imponderable situations! The important thing is to follow up, watch over, recompose and readjust the initial plan. This dynamic, which ranges from 
triggering challenging, intriguing and demanding situations for students to the results they produce, mixing life, current experience and interpretation of the challenges that arise, is the hallmark of the teaching-learning process, seen in its complexity and breadth (FRANCO, 2012, p. 151).

We should note that, in order to have quality education, this movement to monitor, watch over, recompose and readjust the initial planning is essential. The teacher always has to be in tune with the events, building their pedagogical work. It is emphasized that, for the exercise of pedagogical practice, it is essential that the educator be creative, dedicated, a researcher, and attentive to the demands of the current world, with its social restrictions due to the coronavirus. Always keeping in mind that, for the development of quality teaching, research has to be part of the work routine. In this sense, Paulo Freire states that:

There is no teaching without research and no research without teaching. These what-to-dos are found in each other's bodies; while I teach, I keep seeking, researching. I teach because I seek, because I asked, because I ask, and I ask myself. I research to verify, noticing, intervening. Intervening, I educate, and I educate myself. I research to find out what I do not know yet and communicate or announce the novelty (FREIRE, 2005, p.29).

It is evident, then, that the teaching practice is the search, in constant formation, and beyond that, it requires for the teacher to be a researcher, curious and restless of the changes and transformations that take place around them. The teacher is someone who always seeks innovation, that is: information, knowledge, novel teaching techniques, aiming for more dynamic, comprehensive, participative and updated lectures. Freire affirms that: "in the continuing education of teachers, the fundamental moment is that of critical reflection on practice. It is critically thinking about the practice of today or yesterday that the next practice can be improved" (FREIRE, 2005, p. 39)

Therefore, seeking to update and innovate their daily practices, interacting with students, the teacher builds a relationship with their pupil of emancipation and autonomy, where teaching is a way to create possibilities for the production of knowledge. This relationship of trust and reciprocity is only possible if, in our pedagogical practice, we constantly seek to update and learn and, in addition to that, put this into practice in the classroom or in any other space where we will work as teachers. In this sense, Paulo Freire states that: "As a teacher, I need to move with clarity in my practice. I need to know the different dimensions that characterize the essence of the practice, which can make me more secure in my performance" (FREIRE, 2005, p. 68).

We observe, then, that the education professional needs a continuous formation to adequate themselves to the current moment, and, with this, be able to act safely using these novel additional resources. To Freire:

It is the knowledge of History as a possibility and not as a determination. The world is not. The world has been. As a curious, intelligent subjectivity that interferes with the objectivity with which I dialectically relate, my role in the world is not only that of someone who notices what happens, but also that of someone who intervenes as the subject of occurrences. I am not only the object of History but its subject as well. In the world of history, culture, politics, I assert not to adapt, but to change (FREIRE, 2005, p. 76-77).

We can perceive, then, that the teacher is a subject of History, who makes History, and that the relationships they establish with other subjects are relevant, as they are not only a subject who merely observes changes, but also interferes.

In this sense, Freire states that: "the good teacher is the one who manages, while speaking, to bring the student into the intimacy of the movement of their thought." (FREIRE, 2005, p. 86). Getting the students involved, attracting their attention, arousing their interest is a delicate task, but a very pleasurable one.

Thus, for the pedagogical practice to achieve positive results and fulfill its social function, it is necessary to reflect on the distance between academic training and working with students in online classes, which requires a leave from the comfort zone. Thus, Valle states that:

Changing our posture when doing pedagogical work leads us to walk in a dialectical and dialogical perspective. Pointing out ways to make this process less impactful implies decision-making, but it is necessary to consider that any change must have intentionality and must be perceived according to the context experienced by the school community, 
without, therefore, generalizing alternatives under risk of falling into the abyss of common sense (VALLE; MARCOM, 2020, p. 145).

Thus, the necessary posture for a teacher is that which dialogues, listens to different opinions, which knows how to point to alternatives, make decisions and keeps in mind that there is no change without intentionality. Livia Alves Branquinho states that:

The pedagogical practice of education agents at the present time, as well as the conduction of the teaching-learning process in contemporary society, needs to be based on the need for a pedagogical reformulation that prioritizes a training practice for development, where the school is no longer seen as an obligation to be fulfilled by the student, and instead becomes a source of realization of their intellectual knowledge that will motivate them to participate in the process of social development, not as a mere receiver of information, but as an idealizer of practices that favor this process (BRANQUINHO, 2007).

We notice that pedagogical practice comprises some caution and requires much attention from the education agents that are involved in its development, especially with regard to being a motivating teacher who involves students and makes them feel part of the process and thus have a better performance in society. According to Gadotti: "In the information society, the school must serve as a compass to navigate this sea of knowledge" (GADOTTI apud BRANQUINHO, 2007).

This is why the teacher occupies a special place in the teaching-learning process, even more so during these current times of pandemic, where people are fragile and fearful about their future. Gadotti says that:

The educator is a mediator of knowledge, facing the student who is the subject of their own training. They need to build knowledge based on what they do, and for that they also need to be curious, look for meaning in what they do and point out new meanings for what to do with their students (GADOTTI apud BRANQUINHO, 2007).

Thus, we perceive that the construction of knowledge is an arduous task, and one of great responsibility, as this process involves training citizens. In this sense, Professor Camas says: "regardless of technology, it is important to understand, create and give rise to a new school, which sees the curriculum as a path to be built for and by the learners" (CAMAS, 2014). This because, as is well known, curriculum is movement, it is a search, it is a route, a path to be followed. In this sense, the educator needs a permanent look at the constant changes taking place in the world around him as to decide the method of teaching that provides him with greater and better efficiency.

\section{To Freire:}

[...] education is a form of intervention that, in addition to knowledge of well or poorly taught and/or learned contents, implies both the effort to reproduce the dominant ideology and its unmasking. Dialectic and contradictory, education could not be just one or the other of these things, neither just reproducing nor just unmasking the dominant ideology (FREIRE, 2005, p. 98)

Education, as we realize, presents itself in a complex form, where the professor has a unique role in the conduction and action as a mediator of knowledge. Freire says: "as important as the teaching of content is my coherence in the classroom. The coherence between what I say, what I write and what I do" (FREIRE, 2005, p. 13).

This rationale by Freire is also applied to the nonpresential classes of today. Pedagogical practice requires knowledge, discernment, coherence and dedication due to the changes that occur daily in the society where the school is inserted. Being aware and coherent in each action, posture, ways of dialoguing is crucial for quality teaching and learning.

\section{THE ROLE OF THE EDUCATOR IN FACE OF THE NEW CHALLENGES OF REMOTE TEACHING}

Professors play a primordial and essential role in the teaching-learning process; at their hands is the task of teaching and preparing students for the challenges of society, aiming to raise a critical citizen, conscious and prepared to act in our society.

However, for the effectiveness and productiveness of their work, it is necessary for them to be informed on the current events and also to act in consonance with the school, family members and students, that is, a teamwork. This means the professor needs to be interactive. To Silva: "interactive pedagogy is a proposal that values the teacher's role as a mediator of new and recurrent interactions and encourages the network of 
knowledge that students build and the development of novel communicative skills" (SILVA apud SOUSA; MOITA; CARVALHO, 2011, p. 26). It should be noted that interactivity, dialogue, is the most appropriate and safe way for the teacher to develop their teaching in the face of new technological challenges.

We know that technology are instruments developed by humans throughout their history, in order to facilitate and improve their quality of life in this world, and that, currently, they are part of the new challenges in the educational area. However, we need to differentiate information from knowledge. This is the role of the teacher: to create possibilities for students to critically read information, because knowledge is something that comes from the construction of concepts. According to Márcio Roberto Vieira Ramos, Technology is "a set of techniques, methods and processes specific to a science, craft or industry" (RAMOS, 2012, p. 4).

In this sense, we understand that technology arises from the human need that intensely seeks to facilitate life. In this context, education absorbs new technologies, where books, blackboards and marker pens gain new technological reinforcements such as cell phones, laptops, tablets, among other tools. The teacher, Camas, states that:

By novel technologies, we mean the convergence of technology and media to a single tool, which may be a laptop, a cell phone, a tablet, the digital blackboard, a robot, or any other that arises. To an educational standpoint, what is particularly interesting is the collaborative production of knowledge, in which students and professors, together, are also coauthors (CAMAS, 2014).

Therefore, the challenges for education professionals today are enormous and complex. To Freire: "the task of the educator who thinks correctly is exercising as a human being the irrefutable practice of interconnecting, challenging the student with whom they communicate and to whom they communicate, producing their understanding of what has been communicated" (FREIRE apud SOUSA; MOITA; CARVALHO, 2011, p. $35)$. It is noticeable that the teacher has an important role in relation to their dialogue with students, as they have the challenge of making themselves understood.

Thus, it becomes explicit the need for the professor to update themselves, to act competently and to reach their teaching-learning target. That is: educators and students have to constantly exercise with autonomy their educational practices where teaching leads to knowledge and, with that, is able to intervene. To Tarja:

The great evolution and use of new technologies have caused radical changes to the conception of science, and drive people to live with the idea of learning without borders and without prerequisites. All of this implies new ideas of knowledge, teaching and learning, requiring rethinking of the curriculum, the role of the school, the teacher and of the student" (TARJA apud MAINART; SANTOS, 2010, p. 6).

We see that, with the advent of the internet, there is the creation of several possibilities for teaching and learning. That is: many are the options and paths that can be chosen, depending on the training of the professor and on the availability of technological resources by education institutions. One of the problems with novel technologies and remote classes is the difficulty that a significant part of the students faces in not having access to the internet. Thus, Bittencourt says that:

Proposals for the renewal of teaching methods by the current curricula are organized around two axes. The basic and fundamental presupposition is the articulation between method and content [...] The second presupposition is that the current teaching methods must be articulated with the new technologies so that the school can identify itself with the new generations, belonging to the 'media culture'. Technological transformations have affected all forms of communication and introduced new references for the production of knowledge, and this finding interferes with any proposal to change teaching methods (BITTENCOURT, 2008, p. 106-107).

This way, the use of novel technologies for teaching is of great relevance to the performance of the professor with their students. From this perspective, Bulgraen states:

[...] the teacher, in addition to being an educator and transmitter of knowledge, must act, at the same time, as a mediator. That is, the teacher must act as a bridge between the student and knowledge so that, in this way, the student learns how to 'think' and questions for themselves, 
no longer passively receiving information as if they were an educator's deposit. (BULGRAEN apud JUNCKES, 2013, p. 4).

This means that mediation is essential nowadays, that is, teachers need to be aware that they are not the sole holders of knowledge, but a bridge between knowledge and the student. With this attitude on the part of the educator, the student feels that they are the subject of their history, and thus could demonstrate greater autonomy to think, to question and to build new knowledge.

According to scholars, the means of communication: social media, magazines, television, cell phones, currently have a great role and pedagogical power, as they present content, with image and sound, and these attributes enable a more interactive class.

To Maria Lúcia Serafim, “interactive multimedia allows for deep exploration due to its non-linear dimension. Through multimedia, there is a new structure of how to present, demonstrate and structure the information that is learned" (SOUSA; MOITA; CARVALHO, 2011, p. 27).

Thus, we can see that the education professional needs to be continually seeking to learn. This because only through preparation via continuing education will future professionals be included in teaching. With professional training, your resourcefulness in front of the student community will be developed with greater security and satisfactory performance. Freire says that:

As a teacher it is not possible for me to help the student to overcome their ignorance if I do not permanently overcome mine. I cannot teach what I do not know. But this, I repeat, is not knowing that I must only speak, and speak in words that the wind carries. It is knowing, on the contrary, that I must live concretely with the students. The best speech about them is exercising their practice (FREIRE, 2005, p. 95).

In this sense, the Professor plays a relevant role in teaching, and, in learning, their presence is essential to provide scientific knowledge, i.e., rigor in research, providing students with better learning.

\section{THE USE OF NOVEL TECHNOLOGIES AS FACILITATORS OF THE EDUCATION IN THE SOCIAL TRANSFORMATION PROCESS}

The 21 st century presents many technological transformations, and education as path for the development of the human person intellectual capacity needs to adapt itself to those changes, as to fulfill its social role of transforming and raising citizens. The emergence of the coronavirus is also a factor of change in teaching strategies, where schools and teachers, together with students and families, needed to adapt to a teaching model for which they had not been prepared.

Thus, schools need to follow some paths to make good use of new technologies through the digital platform. However, for teaching to reach a greater number of students, it is necessary to strive for the acquisition of technological equipment and for the planning management by teachers. To Erik and Andrew:

In the 21 st century, technological change has become faster and more pervasive. Although the steam engine, the electric motor and the internal combustion engine are impressive technologies, those were not subject to a constant level of continuous improvement as it is seen for digital technologies. Computers are already thousands of times more powerful than they were 30 years ago, and all the evidence suggests that this pace will continue on for at least another decade, and probably longer. Furthermore, computers are, in a sense, the 'universal machine' that can be used in almost all industries and tasks (BRYNJOLFSSON; MCAFEE, 2014, p.65-66).

In this case, what is evident is the need for the school, as well as education professionals, to be up to date and to make use of novel technologies in online classes, as methods to facilitate teaching and the preparation of new professionals to work in schools in a safe way. Moran states that:

Sensory videos, visual, spoken, musical and written language. Languages that interact superimposed, interconnected, added together, not separated. Hence their strength. We are stricken by all senses and in all ways. Video seduces us, informs, entertains, projects us into other times and spaces (MORAN apud 
SOUSA; MOITA; CARVALHO, 2011, p. 30).

This is why the use of new technologies has great relevance today. Bittencourt says that "cultural changes caused by audiovisual media and computers are inevitable, as they generate subjects with new skills and different abilities to understand the world" (BITTENCOURT, 2008, p. 108).

In this sense, it appears that technological tools and the use of the internet require some necessary measures to reduce the impacts of the pandemic on education. Educational institutions, teachers and students, as well as government officials have to mobilize and adapt to the new demands of the education. To Amélia Hamze:

We consider that these new times demand an educational standard that is focused on the development of a set of essential skills and abilities, so that students can fundamentally understand and reflect on reality, participating and acting in the context of a society committed to the future (HAMZE apud BRANQUINHO, 2007).

We then realize that some requirements are important and necessary for the use of new technologies in classrooms to be effective: the educator needs to enjoy what they do and interact with the students, and thus transform their work environment into a pleasant place that motivates and awakens the interest of students, aware of the advancement of technology and information that students face every minute. To Silva:

The teacher who seeks interactivity with their students proposes knowledge; they do not transmit it. In the classroom, they are more than an instructor. Coach, partner, advisor, facilitator guide, collaborator. They are the formulator of problems, the provocateur of situations, architects of paths (SILVA apud SOUSA; MOITA; CARVALHO, 2011, p. 47-48).

It is clear from this that the teacher has a fundamental role as a knowledge facilitator and social transformer.

Thus, the presence of the education professional will always be necessary to mediate knowledge. The teacher's mediation is important for future professionals to leave the classroom fully capable of taking advantage of the possibilities that the digital world offers.
Therefore, the use of novel technologies in the classroom is relevant, as the world is increasingly becoming more and more digital. Education cannot remain outside of this reality; thus, educators can improve their methodology and make their classes more interactive.

\section{FINAL THOUGHTS}

The guiding compass for the analyzes undertaken in this study was aimed at understanding the changes that occurred in the educational process during the covid-19 pandemic period, when classes started to be taught in a non-presential way, through the internet, cell phones, laptops, computers, among others.

We know that schools and teachers have the social role of guiding students and contributing to the development of abilities, skills and their very citizenship. With the covid-19 pandemic, schools adopted remote learning through the use of technology on digital platforms.

It is observable that education during these present times has proved to be quite complex and diversified, due to the appearance of covid-19 and the incorporation of new technologies, such as internet, cell phones, laptop, digital platforms such as Google Meet, Geduc, WhatsApp, cell phone applications, among others.

Therefore, we increasingly realize the importance of education professionals who invest in their teaching practices and, thus, innovate and improve their methods during online classes. It is also necessary for educational institutions to maintain ties with students and their families, so that the learning process actually takes place.

In addition to textbooks, marker pens and blackboards in this new reality, teachers need to use novel technological reinforcements in their pedagogical work. This is because teaching involves a set of factors, such as theory, practice, creativity, competence and dialogue.

We take note as well on the importance of research activity, selection of content to be used so that education fulfills its function of transforming and training citizens aware of their role in society.

It is known that in this new teaching reality, a world of novelties has opened. Where to learn, relearn new ways of teaching and use new techniques and assessment tools makes students come across a knowledge that is full of novelties and, with that, they can realize that this moment demands dedication from everyone; these times demand a tight union between the school, the teachers, students, family members and government agents. 
Therefore, governments need to invest more in education so that all students can have access to classes on digital platforms, in order to minimize the effects caused by the pandemic on the education system. It is everyone's task to join forces to advance the teaching-learning process. We have a lot to do in the fight against school dropouts and for a quality education that no longer excludes, but includes, and thus does not enhance social differences. For the development of this process, the teacher has a primordial role as a mediator of knowledge and, therefore, in the transformation and formation of critical and autonomous citizens.

\section{REFERENCES}

[1] ARAÚJO, Paullyanne Leal de; YOSHIDA, Sônia Maria Pinheiro ferro. Professor: Desafios da Prática Pedagógica na atualidade. www.ice.edu.br $>2009 \ldots$ Acesso em: $16 / 06 / 2016$.

[2] ARROYO, Miguel G. Imagens quebradas: trajetórias e tempos de alunos e mestres. Petrópolis, RJ: Vozes, 2014.

[3] BITTENCOURT, Circe Maria Fernandes. Ensino de História: fundamentos e métodos. São Paulo: Cortez Editora, 2008.

[4] BRANQUINHO, Livia Alves. A Prática Pedagógica da Educação Atual. Disponível em: www.artigos.com>artigosacademicos 2007. Acesso em: 11/02/2017.

[5] BRYNJOLFSSON, Eric; MCAFEE, Andrew. Novas Tecnologias versus Empregabilidade: Como a Revolução Digital acelera a Inovação, desenvolve produtividade e transforma de modo irresistível os empregos e a economia. São Paulo: M. Books do Brasil Editora Ltda. 2014.

[6] CAMAS, Nuria Pons Vilardell. Novas tecnologias facilitam a aprendizagem escolar. Disponível em: www.brasil.gov.br> ...2014. Acesso em: 12/01/2017.

[7] FRANCO, Maria Amélia do Rosário Santoro. Pedagogia e prática docente. São Paulo: Cortez, 2012.

[8] FREIRE, Paulo, Pedagogia da autonomia: saberes necessários à prática educativa. São Paulo: Paz e Terra, 2005.

[9] KIRCHNER, Elenice Ana. Vivenciando os desafios da educação em tempos de pandemia In: PALÚ, Janete, SCHUTZ, Janerton Arlan; MAYER, Leandro (orgs). Desafios da Educação em tempos de pandemia. Editora Ilustração, Cruz Alta: Brasil 2020.

[10] JUNKES, Rosani Casanova. A prática docente em sala de aula: mediação pedagógica. Disponível em: www.linguagem.unisul.br/paginas/eventoa/2013. Acesso em: 16/06/2016.

[11] MAINART, Domingos de A; SANTOS, Ciro M. A importância da tecnologia no processo ensino aprendizagem. Disponível em: www.convibra.com.br>adm_1201.2010.pdf

[12] RAMOS, Marcio Ricardo Vieira. O uso de tecnologias em sala de aula. Revista eletrônica: LENPES-PIBID de ciências sociais - UEL, Edição nº 2, vol1, jul - dez - 2012.
[13] SILVA, Luís Alessandro da; PETRY, Jerônimo Rabello; UGGIONE, NATALINO. Desafios da Educação em tempos de pandemia: como conectar professores desconectados, relatos do Estado de Santa Catarina In: PALÚ, Janete, SCHUTZ, Janerton Arlan; MAYER, Leandro (orgs). Desafios da Educação em tempos de pandemia. Editora Ilustração, Cruz Alta: Brasil 2020.

[14] SOUSA, Robson Pequeno de.; MOITA, Filomena M C da S C; CARVALHO, Ana Beatriz Gomes (orgs.). Tecnologia digital na educação. EDUEPB - Campina Grande - PB, 2013.

[15] VALLE, Paulo Dalla; MARCOM, Jacinta Lúcia; IN: PALÚ, Janete, SCHUTZ, Janerton Arlan; MAYER, Leandro (orgs). Desafios da Educação em tempos de pandemia. Editora Ilustração, Cruz Alta: Brasil 2020. 